\title{
LOOKING FOR CONVERGENCE: STAKEHOLDERS' PERCEPTIONS OF COCOA EXTENSION CONSTRAINTS IN GHANA
}

\author{
F. Baah ${ }^{1}$ and V. Anchirinah \\ Cocoa Research Institute of Ghana, P.O. Box 8, Tafo-Akim, Ghana \\ [ Corresponding author, email: achamfour1966@gmail.com]
}

\begin{abstract}
This study was undertaken with the objective of evaluating the extent of convergence on the part of key stakeholders in the cocoa sector on the problems of cocoa extension and how to address it. The study was carried out in the Atwima Mponua and Amansie West districts of the Ashanti region in 2008 although some of the stakeholders interviewed were outside these districts. Survey research methodology was employed including focus group discussions to obtain information from policy makers, researchers, extensionists, licensed buying companies, input dealers and farmers. The key findings were that all concurred that productivity should be boosted to improve the lot of farmers and that information provision is central to this. However, there was no convergence as to how this could be achieved. It emerged that the state of cocoa extension was deplorable requiring urgent policy intervention. The implications and conclusions are that farmers are not benefitting sufficiently from many years of cocoa research; to move productivity to a higher pedestal, the acknowledged knowledge gap between researchers and farmers need to be bridged.
\end{abstract}

Keywords: Stakeholders, Convergence, Extension, Perceptions, Cocoa

\section{INTRODUCTION}

Cocoa remains the mainstay of the Ghanaian economy accounting for over $40 \%$ of agricultural exports and $12 \%$ of gross domestic product (GDP) (Institute of Statistical Social and Economic Research (ISSER), (2008). It is the main source of livelihood for over 400,000 farm-families and their dependents. Whilst productivity has picked up in recent times, it remains low compared to Ghana's competitors such as Cote d'Ivoire. The low productivity is attributed to a myriad of constraints including low producer prices, pests and diseases infesta- tions, low soil fertility and poor extension support (e.g., MASDAR International Consultants, 1998; Ghana Cocoa Board (COCOBOD), 1995, 1998; Baah, 2006; Ministry of Manpower, Youth and Employment, 2008).

Prior to the year 2000, cocoa extension was undertaken by the now defunct Cocoa Services Division (CSD) of the Ghana Cocoa Board (COCOBOD). The primary aim of CSD was to provide an advisory function for improved cultivation of cocoa, and to achieve this, it employed a modified form of training and visit $(\mathrm{T}$ 


\section{Baah and Anchirinah}

\& V) system using extension methods such as demonstrations, rallies, farmers' fora and the provision of inputs (the input supply functions were later dropped following privatisation). CSD also had a regulatory function. This involved the identification and cutting out of cocoa trees infected with the deadly swollen shoot virus disease. Cocoa therefore had its own research (Cocoa Research Institute of Ghana (CRIG) is still functional and serving the research needs of cocoa farmers) and extension services because it was considered to be of strategic importance to the Ghanaian economy. It is still considered as such but it was felt during the restructuring of the cocoa sector that CSD was not providing cost-effective services to farmers.

Cocoa extension is now the responsibility of the Agricultural Extension Services of the Ministry of Food and Agriculture (MOFA). It has become apparent since 2000 that MOFA was not adequately resourced to take the additional responsibility of providing extension support to the cocoa sector. Studies by Baah (2006, 2007a) and Ministry of Manpower Youth and Employment (2008) indicate that the state of cocoa extension is far from the desired. For instance, in a study of over 3,000 cocoa farming households in 2007 - 2008, the national programme for the elimination of worst forms of child labour in cocoa (Ministry of Manpower, Youth and Employment, 2008) found that over $73 \%$ of farmers have received no extension support in the year preceding the study. A report by Ghana Cocoa Board (2005) into the state of cocoa extension under MOFA came to similar conclusions. These studies and reviews suggest that other models must be found to provide for the information needs of cocoa farmers. How do we address the problem of inadequate information or extension support to Ghana's cocoa farmers? The approach in the past has been to rely on prescriptions from policy makers alone with little or no inputs from other stakeholders such that they invariably fail to address the problem. This study aimed to deviate from this approach by seeking the per- ceptions of all key stakeholders including farmers on how to address the problem of cocoa extension in Ghana.

\section{METHODOLOGY}

The study employed social survey research methodology. This has been defined as an investigation in which systematic measurements are made over a series of cases yielding a rectangle of data. The variables in the matrix are analysed to see if they show any patterns and the subject matter is a social phenomenon (Marsh, 1982). Whereas this definition may suggest the use of standardised questionnaires, De Vaus (2002) emphasised that a survey is not just a particular technique of collecting information; questionnaires are widely used but other techniques such as in-depth interviews and observations can also be used in survey research. It is in this context that this study employed in-depth interviewing and focus group discussions to solicit information from identified key stakeholders in the cocoa sector focussing on the problems of cocoa extension.

The study was carried out in ten purposively selected communities (five of each) in the Atwima Mponua and Amansie West districts of Ashanti Region, Ghana in 2008. The selection was done randomly by the writing of the names of all the communities in the districts based on information obtained from the Produce Buying Company which were then folded and placed in a container and shaken. The papers were picked one at a time without replacement. The selected communities are shown in Table 1.

For the in-depth interviews, ten farmers were purposively selected and interviewed altogether, one from each community based on their perceived depth of knowledge on cocoa identified during the focus group discussions. Other stakeholders interviewed include ten researchers from the Cocoa Research Institute of Ghana, ten extensionists from the district offices of the Ministry of Food and Agriculture (MOFA) and four policy makers, two from the Ghana Cocoa Board and two from the head 
office of MOFA. Focus group interviews were conducted in an informal participatory mode, a point that was emphasised in the introductory remarks by the researchers. It was pointed out that the sessions were not a question and answer one, and that a point made by one could be commented on by others (Casley and Kumar, 1988). Questions did not follow a particular order but there was a checklist to ensure that all issues were covered. Table 2 shows the various focus group discussions held.

Table 1: Districts and communities selected for the study

\begin{tabular}{ll}
\hline District & Selected Communities \\
\hline Atwima Mponua & Akorabourkrom \\
& Otaakrom \\
& Kyereyaaso \\
& Amadaa \\
& Aweafutu \\
& Esaaso \\
Amansie West & Aboaboketekaso \\
& Tetrem \\
& Kobeng \\
& Ahwerewa \\
\hline
\end{tabular}

Table 2: Focus Group Discussions held in Ashanti, 2008

\begin{tabular}{lcc}
\hline Nature of Group & $\begin{array}{l}\text { Number } \\
\text { Interviewed }\end{array}$ & $\begin{array}{l}\text { Mean Group } \\
\text { Size }\end{array}$ \\
\hline $\begin{array}{l}\text { Women cocoa } \\
\text { farmers }\end{array}$ & 2 & 10 \\
$\begin{array}{l}\text { Men cocoa } \\
\text { farmers }\end{array}$ & 4 & 10 \\
$\begin{array}{l}\text { Mixed group of } \\
\text { men and women } \\
\text { cocoa farmers }\end{array}$ & 6 & 23 \\
$\begin{array}{l}\text { Mixed group of } \\
\text { men and women } \\
\text { non-cocoa } \\
\text { farmers }\end{array}$ & 4 & 13 \\
TOTAL & & \\
\hline
\end{tabular}

Source: Survey records (2008). "Non-cocoa farmers were included because MOFA is also responsible for their extension needs
Information from one key stakeholder was cross-checked with another to ensure that inconsistencies were eliminated. A noted shortcoming of the stakeholder analysis employed is the study's inability to bring all the stakeholders together on a common platform due to logistical constraints.

\section{Data analysis}

Content analysis was employed to identify patterns, themes, unique or unusual information via constructed categories such as values, goals, actors, conflict and authority. The schema suggested by Ellen (1984) guided the analysis (see Figure 1). Matrices were employed to capture the varied views of the various stakeholders on issues raised during the in-depth interviews.

\section{RESULTS AND DISCUSSION}

Key stakeholders in the cocoa sector in Ghana

The study sought to identify key stakeholders or actors whose actions or inactions affect the fortunes of the cocoa sector. The outcome is displayed in Table 3 which identifies the stakeholders and why they are critical to the cocoa sector. In terms of importance and influence, the stakeholders as expected, differ. Importance refers to the extent to which a stakeholder is affected by the issue or issues at stake, whilst influence refers to the extent to which stakeholders are able to persuade or coerce others into making decisions, and follow certain courses of action. Small-scale farmers are the most important stakeholders in as far as cocoa cultivation is concerned because they produce nearly all of Ghana's output. However, interactions with the stakeholders indicate that farmers exert little influence in the formulation and implementation of policies that affect their activities and livelihood. On the other hand, Ghana Cocoa Board, the main policy formulator and implementer is the most influential stakeholder (see Figure 2). It is desirable and more sustainable that farmers' role and influence in decision-making processes are strengthened. 


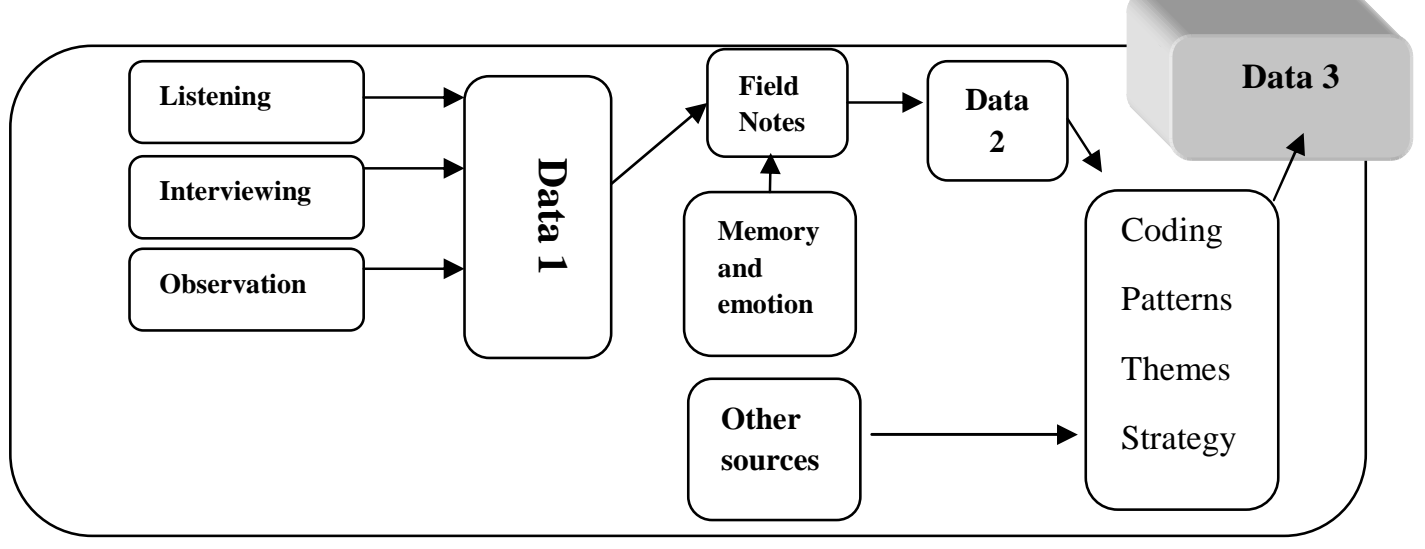

Figure 1: Qualitative data analysis schema

\section{RESULTS AND DISCUSSION \\ Key stakeholders in the cocoa sector in Ghana}

The study sought to identify key stakeholders or actors whose actions or inactions affect the fortunes of the cocoa sector. The outcome is displayed in Table 3 which identifies the stakeholders and why they are critical to the cocoa sector. In terms of importance and influence, the stakeholders as expected, differ. Importance refers to the extent to which a stakeholder is affected by the issue or issues at stake, whilst influence refers to the extent to which stakeholders are able to persuade or coerce others into making decisions, and follow certain courses of action. Small-scale farmers are the most important stakeholders in as far as cocoa cultivation is concerned because they produce nearly all of Ghana's output. However, interactions with the stakeholders indicate that farmers exert little influence in the formulation and implementation of policies that affect their activities and livelihood. On the other hand, Ghana Cocoa Board, the main policy formulator and implementer is the most influential stakeholder (see Figure 2). It is desirable and more sustainable that farmers' role and influence in decision-making processes are strengthened.
Table 3: Key stakeholders in the Ghanaian cocoa sector

\begin{tabular}{|c|c|}
\hline Stakeholders & $\begin{array}{l}\text { Reasons and Key } \\
\text { Interventions }\end{array}$ \\
\hline Farmers & $\begin{array}{l}\text { Main producers of } \\
\text { Ghana's cocoa }\end{array}$ \\
\hline $\begin{array}{l}\text { Ghana Cocoa Board } \\
\text { (COCOBOD) }\end{array}$ & $\begin{array}{l}\text { Main policy makers o } \\
\text { the cocoa sector }\end{array}$ \\
\hline $\begin{array}{l}\text { Ministry of Food and } \\
\text { Agriculture (MOFA) }\end{array}$ & $\begin{array}{l}\text { Policy makers and } \\
\text { service (extension) } \\
\text { provider }\end{array}$ \\
\hline
\end{tabular}

Licensed Buying

Companies (LBC)

Purchasers of cocoa beans and service providers

Cocoa Research Institute of Ghana (CRIG)

Input companies

Farmer organisations (FO)

Service provider (research-based information)

Marketers of agricultural inputs such as pesticides

Mouth piece of farmers and input market-

Source: Survey data (2008) 
Stakeholders' Perceptions of Cocoa Extension Constraints...

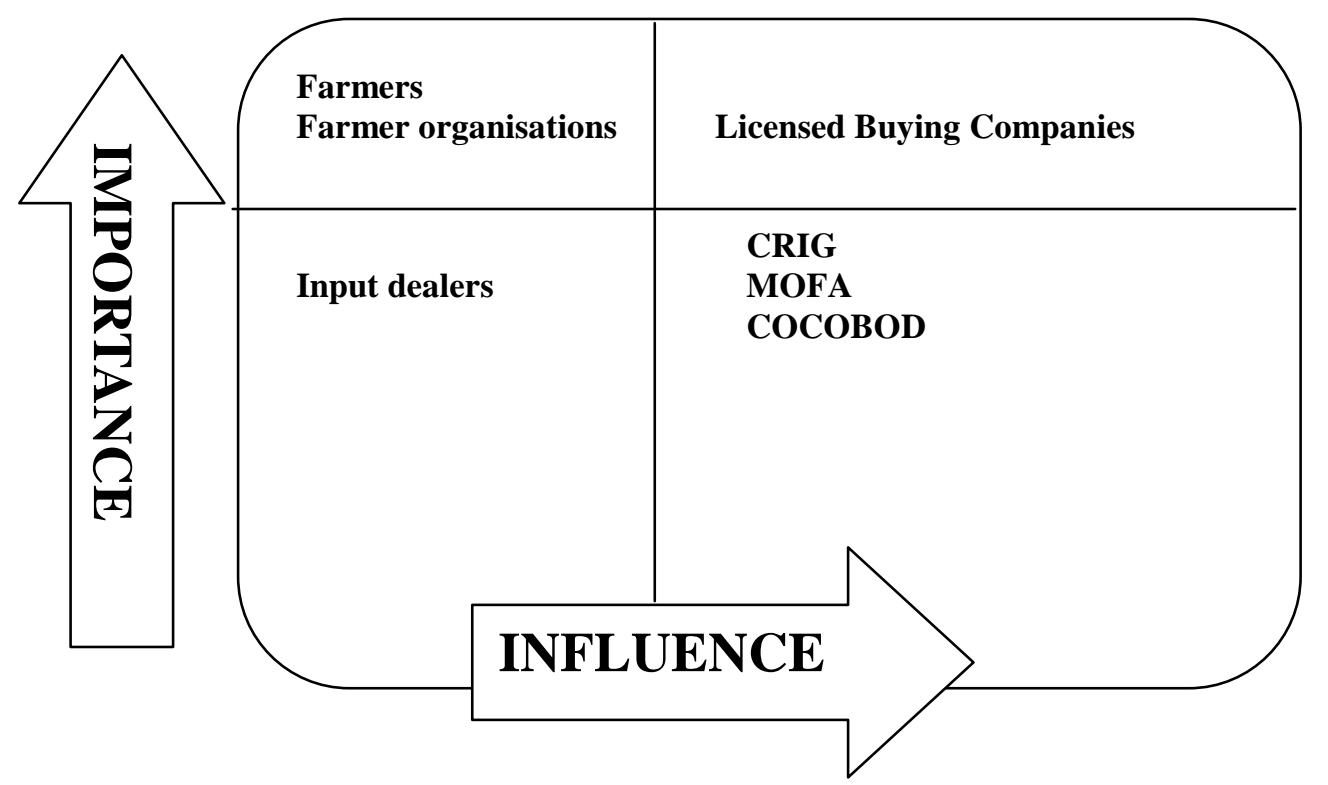

Figure 2: Importance and Influence matrix of stakeholders

It should be noted that the position of any stakeholder in the matrix is based on the authors' interpretation on the basis of experience and deductions from discussions with the stakeholders. The linkage matrix (Table 4) provides insights into the level of interactions between the stakeholders. It was noted that interactions between researchers of CRIG and farmers could be enhanced; farmers were found to have close links with LBCs and their agents and input dealers. Only $15 \%$ of the farmers encountered were members of a farmer association but many non-members nevertheless reported partaking in activities organised by such associations (such as rallies). With respect to COCO$\mathrm{BOD}$, farmers felt remote from it even when it was explained that they are responsible for their bonus payment and that one of them is part of the process that determines the cocoa price they receive. Farmers who reported interacting with CRIG researchers did so via their on-farm trials especially the fertilizer demonstrations (see Appiah, 2004) and their radio sensitization programme.

Table 4: Stakeholders' Linkage Matrix

\begin{tabular}{|l|l|l|l|l|l|l|c|}
\hline $\begin{array}{l}\text { STAKE- } \\
\text { HOLDER }\end{array}$ & $\begin{array}{l}\text { FARM- } \\
\text { ERS }\end{array}$ & $\begin{array}{l}\text { COCO- } \\
\text { BOD }\end{array}$ & $\begin{array}{l}\text { INPUT } \\
\text { DEAL- } \\
\text { ERS }\end{array}$ & $\begin{array}{l}\text { MOF } \\
\text { A }\end{array}$ & CRIG & FO & LBC \\
\hline FARMERS & & + & +++ & + & ++ & ++ & +++ \\
\hline COCOBOD & & & ++ & + & +++ & ++ & +++ \\
\hline $\begin{array}{l}\text { INPUT DEAL- } \\
\text { ERS }\end{array}$ & & & & ++ & +++ & +++ & ++ \\
\hline MOFA & & & & & + & + & + \\
\hline CRIG & & & & & & ++ & ++ \\
\hline FO & & & & & & & +++ \\
\hline LBC & & & & & & & \\
\hline
\end{tabular}

Legend: $+++=$ strong linkage; $++=$ modest linkage $;+$ =Weak linkage. 
56

Baah and Anchirinah

\section{Perceptions of stakeholders}

Since cocoa extension as an activity is part of the entire cocoa sector, stakeholders spoke of the problems of cocoa extension within the context of the general problems facing farmers. Consequently, their perceptions of the general problems of farmers were also captured:

\section{Farmers on the problems of cocoa extension}

The problems of cocoa extension in Ghana as perceived and ranked by the farmer groups are shown in Table 5.

Table 5: Ranking of problems of cocoa extension in Ghana by farmers ( $n=16$ groups)

\begin{tabular}{lcc}
\hline Problem & $\begin{array}{l}\text { Number of } \\
\text { Times Men- } \\
\text { tioned }\end{array}$ & $\begin{array}{l}\text { \% Farmer } \\
\text { Groups }\end{array}$ \\
\hline $\begin{array}{l}\text { Poor linkage } \\
\text { between farm- } \\
\text { ers, research- } \\
\text { ers and exten- } \\
\text { sion officers }\end{array}$ & 16 & 100 \\
$\begin{array}{l}\text { Poorly moti- } \\
\text { vated exten- } \\
\text { sion staff }\end{array}$ & 12 & 75 \\
$\begin{array}{l}\text { Limited fund- } \\
\text { ing of cocoa } \\
\text { extension }\end{array}$ & 9 & \\
$\begin{array}{l}\text { Lack of a } \\
\text { separate exten- } \\
\text { sion system } \\
\text { for cocoa }\end{array}$ & & \\
$\begin{array}{l}\text { Poorly trained } \\
\text { extension staff }\end{array}$ & & \\
\hline
\end{tabular}

\section{Source: Survey data, 2008}

Farmers were concerned by the poor contacts between them, extension officers and researchers.

Policy makers on problems of cocoa farmers These are the views of officials of MOFA and
COCOBOD. Whilst they are policy makers by virtue of their positions and functions, their views expressed here do not necessarily represent the official position of MOFA or COCOBOD. They were of the view that the problems of cocoa farmers could be categorised into:

\section{Technical}

i. Declining soil fertility following decades of nutrient mining without replenishment. They point to the low level of use of fertilizers in cocoa in Ghana compared to countries such as Malaysia and Cote d'Ivoire. They hoped that the on-going Hi-Tech programme to enhance fertilizer use among farmers will be expanded and sustained to enhance productivity.

ii. Farmers' use of low yielding varieties for planting. This it is suggested is due to the low production and supply of improved seeds to farmers especially during the planting period (May-September).

iii. General poor maintenance of cocoa farms leading to low yields.

\section{Economic}

i. Low producer price paid to farmers. Whilst there was consensus that the producer price has been rising in recent years, farmers could be paid more if Government's dependency on cocoa for revenue is reduced.

ii. Lack of credit. Farmers could hardly access loans for the maintenance of their farms. They suggested that the situation is not helped by the general perception amongst the banks that cocoa farmers often fail to honour their credit repayments because they erroneously regard bank credit as 'gift' from the government

\section{Social}

i. Old age of farmers. They contended that the cocoa sector needed to attract the youth to replace the ageing farming popu 
Stakeholders' Perceptions of Cocoa Extension Constraints...

lation who because they are literally 'on their way out' are not inspired to invest in their farms. The issue of the age of cocoa farmers (average age is 55years) came to the fore recently during a stakeholders' workshop to present the results of a national survey on labour use in cocoa (Ministry of Manpower, Youth and Employment, 2008). There was general consensus that the future of Ghana's cocoa is threatened by the country's inability to attract the youth into the sector.

ii. Problems of inheritance, farm fragmentation and litigation. These problems often deter the youth from venturing into cocoa problem. The issue of inheritance and its associated problems of neglect of widows and their children are not helping the drive to get women and the youth into cocoa cultivation.

\section{On cocoa extension}

There was consensus that the current state of cocoa extension was far from desirable. They agreed that contact between extension agents and farmers have declined since the 2000 merger of CSD and MOFA extension. MOFA policy makers persistently blamed COCOBOD for the present state of cocoa extension after the merger. They contended that COCOBOD was supposed to provide funds to MOFA to fund cocoa extension but this was not done. An apparently agitated MOFA official put it this way:

'MOFA did not ask for cocoa extension. It was thrown at the Ministry without any presidential letter or legislative instrument or parliamentary approval (in effect, it was illegal). MOFA requested for funds and staff to do cocoa extension, neither was provided'

The ranking of the key problems of cocoa extension by the policy makers is shown in Table 6.

Responding, COCOBOD officials expressed concern about the breakdown in extension ser-
Table 6: Ranking of problems of cocoa extension in Ghana by Policy

\begin{tabular}{lcc}
\hline Problem & $\begin{array}{l}\text { Number of } \\
\text { Times Men- } \\
\text { tioned }\end{array}$ & $\begin{array}{l}\text { \% Policy } \\
\text { Makers }\end{array}$ \\
\hline $\begin{array}{l}\text { Limited fund- } \\
\text { ing of cocoa } \\
\text { extension }\end{array}$ & 4 & 100 \\
$\begin{array}{l}\text { Lack of a } \\
\text { separate exten- } \\
\text { sion system } \\
\text { for cocoa }\end{array}$ & 3 & 75 \\
$\begin{array}{l}\text { Poorly moti- } \\
\text { vated exten- } \\
\text { sion staff }\end{array}$ & 2 & \\
$\begin{array}{l}\text { Poor linkage } \\
\text { between farm- } \\
\text { ers, research- } \\
\text { ers and exten- } \\
\text { sion officers }\end{array}$ & 2 & 50 \\
$\begin{array}{l}\text { Poorly trained } \\
\text { extension staff }\end{array}$ & & \\
\hline
\end{tabular}

Source: Survey data, 2008

vices to farmers since the merger. A recent survey of over 3,000 cocoa households revealed that $73 \%$ of respondents have not met an extension agent or received any extension support in a year (Ministry of Manpower, Youth and Employment, 2008). Clearly, farmers will do without wrangling over policy changes that has affected them badly. What is required is implementation of policy recommendations that have emerged from recent reviews of the cocoa extension situation (for instance the Cocoa Extension Review Committee Report, (Ghana Cocoa Board, 2005).

\section{Researchers}

The researchers of CRIG spoke in their personal capacities and not as representatives of CRIG. The main problem of the cocoa sector from their perspective is getting research recommendations developed at CRIG to farmers. 
This is on the basis that cocoa extension is not effective since MOFA does not have the resources to do so. They contend that other institutions including CRIG should be resourced to undertake cocoa extension using the radio especially and television to reach informationtrapped farmers. This position is supported by many workers (see Baah, 2006, 2008a; Röling, 1986) who contend that research should be seen as part of a knowledge system with many actors all contributing to a knowledge pool. In this perspective, research does not end with technology generation; greater interaction with actors or stakeholders whose livelihoods the outcomes of research impinges on is desired. A researcher interviewed summed it up this way:

'CRIG cannot pretend to be only concerned about research and leave extension to another body. So long as farmers cannot receive their much-needed technological and allied information, CRIG's work is incomplete' (Source: Interview reports, 2008).

They also suggested that farmer organisations and the licensed buying companies should be empowered to undertake cocoa extension since they are in close contact with farmers in the farming communities. They were of the opinion that despite the failure of public sector cocoa extension support to farmers, some farmers who regard cocoa farming as a business often seek the information and other inputs they need, and mentioned several instances of farmers travelling from far and near to CRIG for information and advice. In their view, such proactive and business-minded farmers represent the future face of cocoa cultivation. Unfortunately, such farmers are in the minority and that the solution in restoring Ghana cocoa to its rightful place lies in a concerted media campaign using the radio and other media backed by CRIG and other stakeholders to present cocoa as the future and a source of secured income and livelihood. Researchers' ranking of the main problems of cocoa extension is presented in Table 7.
Table 7: Ranking of problems of cocoa extension in Ghana by Researchers $(n=10)$

\begin{tabular}{lcc}
\hline Problem & $\begin{array}{l}\text { Number of } \\
\text { Times Men- } \\
\text { tioned }\end{array}$ & $\begin{array}{l}\% \text { Research- } \\
\text { ers }\end{array}$ \\
\hline $\begin{array}{l}\text { Limited fund- } \\
\text { ing of cocoa } \\
\text { extension }\end{array}$ & 10 & 100 \\
$\begin{array}{l}\text { Lack of a } \\
\text { separate exten- } \\
\text { sion system } \\
\text { for cocoa }\end{array}$ & 9 & 90 \\
$\begin{array}{l}\text { Poor linkage } \\
\text { between farm- } \\
\text { ers, research- } \\
\text { ers and exten- } \\
\text { sion officers }\end{array}$ & 7 & \\
$\begin{array}{l}\text { Poorly moti- } \\
\text { vated exten- } \\
\text { sion staff }\end{array}$ & & \\
$\begin{array}{l}\text { Poorly trained } \\
\text { extension staff }\end{array}$ & 5 & \\
\hline
\end{tabular}

Source: Survey data, 2008

\section{Extensionists}

The extensionists were mainly middle cadre extension staff of MOFA in the Ashanti region. In addition, senior policy makers in Accra were also interviewed in the course of the study. On the current state of cocoa extension, they agreed that MOFA is not able to provide extension support to farmers as was perhaps the case when cocoa extension was undertaken by COCOBOD. They contend that this is the case because MOFA is under resourced with many extension agents having no means of transport to reach out to farmers. In addition, agents' remuneration is very poor such that it does not motivate them to give their best. They also mentioned the low level of knowledge on cocoa amongst the MOFA extension agents as a major problem. When it was suggested that the retraining of MOFA agents in cocoa husbandry 
practices was part of the activities planned prior to the merger and soon after, the response was that this was indeed the case but there remain a backlog of agents to be trained. What then is the way forward for cocoa extension? The general consensus was that cocoa extension should go back to COCOBOD which is perceived to have the needed resources to undertake cocoa extension. When they were reminded that under Cocoa Services Division (CSD) of COCOBOD farmers still complained about receiving inadequate extension support (see MASDAR International Consultants, 1998; Baah, 2002, 2008b) the response was that though CSD extension agents were relatively better resourced and remunerated, the monitoring of their activities was very poor such that many merely used their time in the communities in other engagements. Extension officers ranked the key problems of cocoa extension in Ghana as shown in Table 8.

Table 8: Ranking of problems of cocoa extension in Ghana by Extension officers $(n=10)$

\begin{tabular}{lcc}
\hline Problem & $\begin{array}{l}\text { Number of } \\
\text { Times Men- } \\
\text { tioned }\end{array}$ & $\begin{array}{l}\text { \% Extension } \\
\text { Officers }\end{array}$ \\
\hline $\begin{array}{l}\text { Poorly moti- } \\
\text { vated exten- } \\
\text { sion staff }\end{array}$ & 10 & 100 \\
$\begin{array}{l}\text { Lack of a } \\
\text { separate exten- } \\
\text { sion system } \\
\text { for cocoa }\end{array}$ & 8 & 80 \\
$\begin{array}{l}\text { Limited fund- } \\
\text { ing of cocoa } \\
\text { extension }\end{array}$ & 7 & \\
$\begin{array}{l}\text { Poor linkage } \\
\text { between farm- } \\
\text { ers, research- } \\
\text { ers and exten- } \\
\text { sion officers }\end{array}$ & & \\
$\begin{array}{l}\text { Poorly trained } \\
\text { extension staff }\end{array}$ & & \\
\hline
\end{tabular}

Source: Survey data, 2008

\section{Licensed Buying Companies}

There are twenty-two licensed buying companies purchasing cocoa from farmers since the liberalization of the internal marketing of cocoa in 1993. However, the erstwhile state owned Produce Buying Company (PBC) continues to dominate the market (with about 53\% share). Consequently, their presence could be seen in all the study villages, with their purchasing clerks in regular interactions with farmers. Nevertheless, efforts were made to seek the views of other companies in respect of the issues being investigated. The companies whose perceptions are synthesised here are:

1. Produce Buying Company Limited

2. Akuafo Adamfo Marketing Company Limited

3. Kuapa Kookoo Limited

4. Adwumapa Limited

Only the management of Kuapa Kookoo Limited were available for discussion in the course of the study. For the other companies, their district officers and purchasing clerks were interviewed.

\section{On the current state of cocoa extension}

They were unanimous that farmers are not being provided the necessary extension support and attributed it to the merger of CSD with MOFA extension. One purchasing clerk (PC) put it this way:

'Cocoa extension is non-existent. CSD should be brought back; cocoa requires its own extension set up'

But another was not convinced that bringing back CSD will solve the problem:

'The erstwhile CSD agents were not working. We live here with them; they were cocoa farmers or businessmen running their stores. The problem is supervision; until an effective mechanism is put in place to monitor the activities of extension staff, many will continue to receive salaries without working' 
But what about suggestions that LBCs could provide extension support to farmers through their agents? They welcomed the concept but admitted that it will require considerable training of PCs with backstopping from CRIG researchers. How the representatives of the LBCs ranked the problems of cocoa extension is shown in Table 9.

Table 9: Ranking of problems of cocoa extension in Ghana by Licensed Buying Companies $(n=18,8$ district officers and 10 PCs).

\begin{tabular}{|c|c|c|}
\hline Problem & $\begin{array}{l}\text { Number of } \\
\text { Times Men- } \\
\text { tioned }\end{array}$ & \% LBC Staff \\
\hline $\begin{array}{l}\text { Poor linkage } \\
\text { between farm- } \\
\text { ers, research- } \\
\text { ers and exten- } \\
\text { sion officers }\end{array}$ & 17 & 94.5 \\
\hline $\begin{array}{l}\text { Poorly moti- } \\
\text { vated exten- } \\
\text { sion staff }\end{array}$ & 16 & 88.89 \\
\hline $\begin{array}{l}\text { Limited fund- } \\
\text { ing of cocoa } \\
\text { extension }\end{array}$ & 12 & 66.67 \\
\hline $\begin{array}{l}\text { Lack of a } \\
\text { separate exten- } \\
\text { sion system } \\
\text { for cocoa }\end{array}$ & 10 & 55.56 \\
\hline $\begin{array}{l}\text { Poorly trained } \\
\text { extension staff }\end{array}$ & 8 & 44.44 \\
\hline
\end{tabular}

Source: Survey data, 2008

Is there any convergence in the perceptions of these stakeholders in respect of the current state of cocoa extension and how cocoa farmers' information needs might be met?

Points of convergence were:

i. The state of cocoa extension is far from the desired. MOFA is clearly not doing cocoa extension or is incapable of doing it. It appears that MOFA were expecting resources from COCOBOD when they agreed to take on the responsibility of providing cocoa farmers with needed technological and allied information. COCOBOD on the other hand does not have a hand in how MOFA carried out its responsibility

ii. All the stakeholders in the cocoa sector by virtue of their closeness to farmers and existence of communication channels between them and farmers can act as knowledge repositories to be accessed by farmers. What is required to bring this to fruition is a conscious effort to upgrade the skills of all the identified stakeholders such that by their interactions with farmers, they can benefit in terms of making informed decisions that impinge positively on their productivity.

iii. There is the need to move farmers beyond the decision to act to the point where they actually carry out production and investment decisions that benefit them, their farms and the country. Providing farmers with needed information will not only enhance their decision making processes, it could also provide vital links to markets (Franzel, Cooper and Denning, 2001) and perhaps more critically, it can facilitate and influence policy change (Sanginga et al., 2004).

iv. There is the urgent need to strengthen farmers' organisations and groups. The benefits of farmers' organisations and groups have been demonstrated (Davis et al., 2004; Bentley and Baker, 2000; Baah, 2008). Because there will always be a limited number of extension workers, there is the urgent need in consultation with community leaders to form groups or strengthen existing ones to be used not only as points of contact with extension 
and research, but also to galvanise farmers to demand for the services they want.

To establish the extent of agreement between the stakeholders on the problems of cocoa extension in Ghana, Kendall's coefficient of concordance was employed using information in Tables 5, 6, 7, 8 and 9. The results suggest a fair agreement between the stakeholders (Kendall's concordance was 0.5 , significant at $\mathrm{p}=0.05$, critical value $=112.30$. Coefficient $=$ 0.518 ; Adjusted for ties $=0.523$; Sample size $=$ 5 ; Number of samples $=5$; Sum of squares $=$ 129.5).

The stakeholders reviewed in this paper could be likened to a system (the cocoa system in this case) which is expected to operate synergistically to achieve its goal. The goal clearly in the cocoa system is to raise farmer productivity and incomes. Is there any evidence of this being achieved? Whilst cocoa productivity has picked up in recent times (output peaked 740,000 metric tonnes in 2006/7) to about $400 \mathrm{~kg} / \mathrm{ha}$ (Ministry of Manpower, Youth and Employment, 2008), stakeholders agree that this is far from the potential as obtainable on research farms - 1,000kg/ha (Manu and Tetteh, 1987). Table 4 (the linkage matrix) suggests that the level of interaction between some of the stakeholders need to improve for synergy to be achieved. If this is not done, as Röling and Engel (1991) and Checkland (1981) warned, the system will not achieve its objectives.

\section{CONCLUSIONS}

This study has adduced evidence suggesting that stakeholders in the cocoa sector concur that cocoa farmers are not receiving the information and extension support that they require. The general consensus was that this situation needs to be rectified quickly if farmer productivity is to be raised. Interactions with farmers in this study suggest that cocoa farmers have a generally positive attitude towards cocoa cultivation which has kept many in the enterprise despite years of difficulties. It also been deciphered that underlying the positive attitudinal disposi- tion are underlying beliefs which needs to be reinforced (such as the belief that owning a cocoa farm means that one has a future) through coordinated media and communication strategy such that these positive beliefs suppress any negative ones that may linger. Without a robust functioning extension support system, such an objective cannot be achieved.

Indications are that Government is in the process of resolving the cocoa extension issue. Stakeholders are unanimous that this should be done swiftly. It is hoped that their request is granted quickly so that extension could provide the focal point for the interactions of all the stakeholders identified in this study to achieve synergy in the cocoa system.

\section{ACKNOWLEDGEMENTS}

The authors are grateful to the editorial committee of CRIG for reviewing the paper and providing constructive criticisms. This paper is published by the kind permission of the Executive Director of the CRIG.

\section{REFERENCES}

Appiah, M.R. (2004). Impact of Cocoa Research Innovations on Poverty Alleviation in Ghana. Fellowship Inaugural Lectures, Ghana Academy of Arts and Sciences, Accra.

Arnaiz, M.E.O., Merrill-Sands, M. and Mukwende, B. (1995). The Zimbabwe farm ers' union: Its current and potential role in technology development and transfer. Agricultural Research and Extension Net work Paper. London: Overseas Development Institute.

Baah, F. (2002). Towards a Pluralistic Approach in Extension Services Delivery to Ghanaian Cocoa Farmers. Journal of the Ghana Science Association, 4 (1): 78-82.

Baah, F. (2006). Cocoa cultivation in Ghana: an analysis of farmers' information and knowledge systems and attitudes. $\mathrm{PhD}$ thesis, Institute for International Develop- 
ment and Applied Economics, University of Reading, UK, 292pp.

Baah, F. (2007). Meeting the information needs of Ghanaian cocoa farmers: are farmer field schools the answer? Journal of Science and Technology, 27 (3): 163-173.

Baah, F. (2008a). Harnessing Farmer Associations as Channels for Enhanced Manage ment of Cocoa Holdings in Ghana. Scientific Research and Essays 3 (9): 195-200.

Baah, F. (2008b). Dissemination Pathways for Cocoa Research Results in Ghana; The potential role of the radio. Ghana Journal of Agricultural Science, 41 (1): 69-77.

Bentley, J. W. and Baker, P. S. (2000). Columbian coffee growers' federation: organ ised, successful smallholder farmers for 70 years. Agricultural Research and Ex tension Network paper 100. London: Overseas Development Institute

Bingen, J., Carney, D. and Dembele, E. (1995).The Malian union of cotton and food crops producers. AgREN Occasional paper, London: Overseas Development Institute.

Casley, D. J. and Kumar, K. (1988). The Collection, Analysis and Use of Monitoring and Evaluation Data. Washington: D.C: The World Bank/John Hopkins University Press.

Checkland, P. (1981). Systems Thinking, Systems Practice. Chichester: John Wiley and Sons.

Ghana Cocoa Board (1995). Report on Causes of Recent Decline in Cocoa Production and Measures to Revamp the Sector. Accra: Ghana Cocoa Board.

Ghana Cocoa Board (1998). Report on the Seminar on the future of the Cocoa Indus- try, Akosombo, 13-15 May 1998.

Ghana Cocoa Board (2005). A report on the review of cocoa extension under the Ministry of Food and Agriculture (MOFA). Accra: Ghana Cocoa Board (COCOBOD), 25pp.

Davis, K., Franzel, S., Hildebrand, P., Irani, T . and Place, N. (2004). Extending Technologies among small-scale Farmers in Meru, Kenya: Ingredients for Success in Farmer Groups. Journal of Agricultural Education and Extension, 10 (2): 53-62.

De Vaus, D. (2002). Surveys in Social Research ( $5^{\text {th }}$ Edition). London: Routledge

Ellen, R. F. (1984, ed). Ethnographic research: A guide to general conduct. Orlando: Academic Press.

Franzel, S., Cooper, P. J. M. and Denning, G.L. (2001). Scaling up the benefits of Agroforestry Research: Lessons learned and Research Challenges. Development in Practice, 11 (4): 524-534.

Institute of Statistical, Social and Economic Research (2008). The State of the Ghana ian Economy in 2007. Legon: Institute of Statistical, Social and Economic Research (ISSER), University of Ghana.

Ministry of Manpower, Youth and Employment (2008). Labour survey of cocoa farming households in Ghana. Accra: National Programme for the Elimination of Worst Forms of Child Labour in Cocoa / Ghana Cocoa Board.

Marsh, C. (1982). The Survey Method: The Contribution of Surveys to Sociological Explanation. London: George Allen and Unwin.

MASDAR International Consultants (1998). Socio-economic Study of Cocoa Farming 
in Ghana. Consultancy Report, Accra: Ghana Cocoa Board / MASDAR International Consultants.

Manu, M and Tetteh, E. K. (1987). Summary of Research Recommendations. Tafo: Cocoa Research Institute of Ghana (CRIG).

Röling, N. (1986). Extension Science: Information Systems in Agricultural Development, Cambridge: Cambridge University Press.

Röling, N. and Engel, P. G. H. (1991). The Development of the concept of Agricultural Knowledge and Information Systems (AKIS): Implications for extension. In: Rivera, W.M and Gustafson, D. J (eds),
Agricultural Extension: Worldwide Institutional Evolutions and Forces for Change pp. 125-137. Amsterdam: El- s e v i e r Publishers.

Sanginga, P. C., Kamugisha, R., Martin, A., Kakuru, A. and Stroud, A. (2004). Facilitating Participatory Processes for Policy Change in Natural Resource Management: Lessons from the highlands of SouthWestern Uganda. Ugandan Journal of Agricultural Sciences, 9: 958-970.

Umali, D. L and Schwartz, L. (1994). Public and private agricultural extension: be yond traditional frontiers. World Bank Discussion Paper 236, Washingt o n D.C.: The World Bank. 